Schatz, A. (1952). J. gen. Microbiol. 6, 329-335.

\title{
Uptake of Carbon Dioxide, Hydrogen and Oxygen by Hydrogenomonas facilis
}

\author{
By A. SCHATZ* \\ Hopkins Marine Station, Stanford University, Pacific Grove, California, U.S.A.
}

SUMMARY: The simultaneous uptake of $\mathrm{CO}_{2}, \mathrm{H}_{2}$, and $\mathrm{O}_{2}$ by non-proliferating cells of Hydrogenomonas facilis was studied by means of a new method employing ordinary Warburg vessels each provided with one stopper side-arm and one vent side-arm. $H$. facilis effected the same overall reaction as that carried out by certain anaerobically adapted green algae: $6 \mathrm{H}_{2}+2 \mathrm{O}_{2}+\mathrm{CO}_{2} \rightarrow\left(\mathrm{CH}_{2} \mathrm{O}\right)+5 \mathrm{H}_{2} \mathrm{O}$. In an atmosphere of $\mathrm{CO}_{2}$ and $\mathrm{H}_{2}$, no $\mathrm{CO}_{2}$ fixation accompanied the quantitative reduction of nitrate to nitrite by molecular $\mathrm{H}_{2}$; nor was there any change in concentration of bicarbonate or in total gas pressure when acetone, pyruvate, or $\alpha$-ketoglutarate were added.

The interest attached to the comparative biochemistry of $\mathrm{CO}_{2}$ fixation prompts the description of a technique for investigating the gaseous metabolism of Hydrogenomonas facilis, a bacterium which oxidizes molecular $\mathrm{H}_{2}$ with $\mathrm{O}_{2}$, and simultaneously assimilates $\mathrm{CO}_{2}$ (Schatz \& Bovell, 1952). The problem, then, is to measure the simultaneous uptake of $\mathrm{CO}_{2}, \mathrm{H}_{2}$ and $\mathrm{O}_{2}$. To investigate the metabolism of certain anaerobically adapted green algae which fix $\mathrm{CO}_{2}$ while carrying out the oxyhydrogen reaction, Gaffron (1942) employed specially constructed Warburg vessels. For the work with $\boldsymbol{H}$. facilis, only the ordinary 2-side-arm (one stopper arm, one vent arm) flasks with centre wells were available. This made it necessary to develop the present method which allowed an analysis of the interrelationships among these three gases in the metabolism of $\boldsymbol{H}$. facilis.

\section{METHODS}

The procedure for obtaining autotrophically grown cells of $\boldsymbol{H}$. facilis for investigating its hydrogenase has already been described (Schatz \& Bovell, 1952). Similar preparations were used to study fixation of $\mathrm{CO}_{2}$. For this, the starting conditions were as follows:

$$
\text { Atmosphere: } 10 \% \text { air }\left(=2 \% \mathrm{O}_{2}\right), 1 \% \mathrm{CO}_{2} \text {, and } 89 \% \mathrm{H}_{2}
$$

\begin{tabular}{|c|c|c|}
\hline Vent side-arm & Main vessel chamber & Stopper side-arm \\
\hline $\begin{array}{l}\text { Loosely rolled } 1 \times 2 \mathrm{~cm} \text {. } \\
\text { strip of filter-paper; } 3-4 \\
\mathrm{~cm} \text {. of rubber tubing on } \\
\text { end of vent }\end{array}$ & $\begin{array}{l}\text { Cells suspended in } 2 \cdot 0 \mathrm{ml} \text {. } \\
\text { M/30 Sørensen's phos- } \\
\text { phate buffer (pH } 7 \cdot 17) \text {; } \\
c .85 \mu \mathrm{l} \text {. } \mathrm{CO}_{2} \text { present as } \\
\text { dissolved bicarbonate }\end{array}$ & $\begin{array}{l}0.1 \mathrm{ml} \text {. freshly prepared } \\
\text { aqueous pyrogallol plus } \\
0 \cdot 1 \mathrm{ml} .2 \mathrm{~N}-\mathrm{H}_{2} \mathrm{SO}_{4} \text { con- } \\
\text { taining } 0 \cdot 2 \% \mathrm{HgCl}_{2}\end{array}$ \\
\hline
\end{tabular}

Volume of the flasks was $18 \mathrm{ml} .( \pm 1 \mathrm{ml}$.$) . All experiments were carried out$ at $30^{\circ}$. Concentrations of $\mathrm{O}_{2}$ and $\mathrm{CO}_{2}$ much above those indicated proved impractical; when large residual volumes of unassimilated $\mathrm{O}_{2}$ and $\mathrm{CO}_{2}$ were

* Present address: Haskins Laboratories, 305 E. 43rd Street, New York 17, N.Y. 
absorbed (to be discussed) by the subsequently added alkaline pyrogallol, the Brodie solution was sucked into the main vessel chamber.

After the desired interval, the acid mixture from the stoppered side-arm was tipped in and instantaneously halted metabolism. Equilibration following the release of $\mathrm{CO}_{2}$ from the bicarbonate usually required $15 \mathrm{~min}$. To determine total $\mathrm{CO}_{2}$ after tipping in acid, the open end of the manometer was corked and the assembly then removed from the water-bath and set in a rack without danger that the Brodie solution would be sucked over into the flask chilled to room temperature.

With a finely drawn Pasteur pipette, the vent arm channel and the rubber tubing were filled with $\mathbf{5 0} \%$ KOH. A $\mathbf{0 . 2}$ ml. pipette charged with the same solution was firmly inserted in the rubber and the vent cautiously rotated to allow $0.200 \mathrm{ml}$. (or a similar accurately measured volume close to $0.200 \mathrm{ml}$.) of alkali to drain into the side-arm where it was immediately absorbed by the filter-paper. It was not necessary to replace all air in the vent arm channel and rubber joint, provided the alkali entered at a rate such that small trapped air bubbles neither rose into the pipette nor were driven down into the side-arm. After return of the assembly to the bath and removal of the cork from the end of the manometer, the absorption of $\mathrm{CO}_{2}$ was complete in c. $15 \mathrm{~min}$.

Mixing the acidified killed cell suspension in the main vessel chamber with the KOH-filter-paper in the vent side-arm produced alkaline pyrogallol which absorbed all residual $\mathrm{O}_{2}$ within 25 min.

The determination of bicarbonate was direct. The values obtained for total $\mathrm{CO}_{2}$ and $\mathrm{O}_{2}$ were obtained indirectly and represented the unconsumed fractions of these gases. The amounts of $\mathrm{CO}_{2}$ and $\mathrm{O}_{2}$ actually assimilated by $\mathrm{H}$. facilis were calculated by subtraction:

total initial gas - unused or residual gas $=$ gas consumed by cells.

To determine the consumption of $\mathrm{H}_{2}$, the $\mathrm{CO}_{2}, \mathrm{H}_{2}$ and $\mathrm{O}_{2}$ initially present only as gases were considered. Since $\mathrm{N}_{2}$ was not fixed by $\boldsymbol{H}$. facilis (Schatz \& Bovell, 1952) nor absorbed by alkaline pyrogallol, it was inert and disregarded in the computations. However, the increase in volume of liquid resulting from the addition of $\mathbf{0 . 2 0 0} \mathrm{ml}$. of $\mathrm{KOH}$ solution through the vent affected manometric readings as would a non-compressible fluid. For the most accurate work this necessitated the use of corrected values for $K_{\mathrm{O}_{\mathrm{a}}}$ and $K_{\mathrm{CO}_{\mathrm{a}}}$ (Umbreit, Burris \& Stauffer, 1949) in all calculations following the introduction of alkali.

Since the solubilities of $\mathrm{O}_{2}$ and $\mathrm{H}_{2}$ are small and numerically close:

$$
\alpha_{\mathrm{H}_{2}}^{30 \circ}=0.02 \text { and } \alpha_{\mathrm{O}_{2}}^{30}=0.03
$$

the oxygen constant $K_{\mathrm{O}_{2}}$ was employed for both gases (as was done by Gaffron, 1942) as well as in the computations for the volume of alkali added through the vent.

In computing the amount of each gas assimilated $\left(-\Delta \mathrm{CO}_{2},-\Delta \mathrm{H}_{2}\right.$ and $\left.-\Delta \mathrm{O}_{2}\right)$, the following designations were employed: 


\begin{tabular}{|c|c|c|}
\hline Time & $\begin{array}{l}\text { Mm. } \\
\text { manometer } \\
\text { reading }\end{array}$ & Gas \\
\hline $\begin{array}{l}\text { Zero (start of experi- } \\
\text { ment) }\end{array}$ & $a$ & $\begin{array}{c}C_{b}=\mathrm{CO}_{2} \text { present as bicarbonate. } \\
C_{i}, H_{i} \text { and } O_{i}=\text { total initial } \mathrm{CO}_{2}, \\
\mathrm{H}_{2} \text { and } \mathrm{O}_{2} \text { present as gases }\end{array}$ \\
\hline After tipping in acid & $\boldsymbol{b}$ & $\begin{array}{l}C_{b}=\mathrm{CO}_{2} \text { released from bicarbo- } \\
\text { nate in the control flask. } C_{f}= \\
\text { total final (unused) } \mathrm{CO}_{2}\end{array}$ \\
\hline $\begin{array}{l}\text { After addition of } \\
\text { KOH to vent arm }\end{array}$ & $c$ & $O_{f}=$ total final (unused) $O_{\mathbf{g}}$ \\
\hline After KOH tip & $d$ & $H_{f}=$ total final (unused) $\mathbf{H}_{2}$ \\
\hline
\end{tabular}

The bicarbonate content of the control flask was taken as a constant for all vessels since the $\mathrm{pH}$, the volume of liquid, and the partial pressure of $\mathrm{CO}_{2}$ were identical in all vessels at the beginning of the experiment. The atmospheric concentration in terms of $\mu \mathrm{l}$. of $\mathrm{CO}_{2}, \mathrm{H}_{2}$ and $\mathrm{O}_{2}$ in all reaction vessels at zero time was calculated by direct proportion from the values for $V_{g}$, the gas volume which was known for all flasks, and the atmospheric concentration of the control vessel, which was analysed at the beginning of the experiment. In the control vessel,

so that $\quad \begin{aligned} & -\Delta \mathrm{CO}_{2}=-\Delta \mathrm{H}_{2}=-\Delta \mathrm{O}_{2}=0, \\ & C_{f}=C_{i}+C_{b}, \quad H_{f}=H_{i} \text { and } O_{f}=O_{i} \text {. }\end{aligned}$

Thus, for computing $-\Delta \mathrm{CO}_{2}$, let $200 / K_{\mathrm{O}_{2}}=\mathrm{mm}$. increase in manometric reading due to introduction of $200 \mu \mathrm{l}$. of $\mathrm{KOH}$ solution into the vent side-arm; and $b+200 / K_{\mathrm{O}_{\mathbf{3}}}=$ theoretical manometric reading if $\mathrm{KOH}$ absorbed no gas. But since $C_{f}$ is quantitatively removed by $\mathrm{KOH}$,

from which $\quad \begin{aligned} b & +200 / K_{\mathrm{O}_{3}}-C_{f} / K_{\mathrm{CO}_{2}}=c, \\ C_{f} & =K_{\mathrm{CO}_{3}}\left(b-c+200 / K_{\mathrm{O}_{2}}\right) .\end{aligned}$

Therefore,

$$
-\Delta \mathrm{CO}_{2}=C_{i}+C_{b}-C_{f}=C_{i}+C_{b}-K_{\mathrm{CO}_{2}}\left(b-c+200 / K_{\mathrm{O}_{2}}\right) .
$$

In the control vessel, $-\Delta \mathrm{CO}_{2}=0$, so that

$$
C_{i}=K_{\mathrm{CO}_{\mathrm{z}}}\left(b-c+200 / K_{\mathrm{O}_{3}}\right)-C_{b} .
$$

This expresses the relationship between the concentration of bicarbonate and gaseous $\mathrm{CO}_{2}$ at zero time.

After mixing the acidified cell suspension in the vessel with $\mathrm{KOH}$ on the filter-paper in the vent side-arm, both $C_{f}$ and $O_{f}$ are completely absorbed by the alkaline pyrogallol. As a result

and

$$
\begin{gathered}
c-O_{f} / K_{\mathrm{O}_{\mathrm{z}}}=d, \text { or } O_{f}=K_{\mathrm{O}_{\mathbf{z}}}(c-d), \\
-\Delta \mathrm{O}_{2}=O_{i}-O_{f}=O_{i}-K_{\mathrm{O}_{2}}(c-d) .
\end{gathered}
$$

To calculate $-\Delta \mathbf{H}_{2}$, let

and

$$
\begin{gathered}
H_{i} / K_{\mathrm{O}_{\mathrm{z}}}=a-C_{i} / K_{\mathrm{CO}_{\mathrm{z}}}-O_{i} / K_{\mathrm{O}_{\mathfrak{z}}}, \\
H_{f} / K_{\mathrm{O}_{\mathrm{z}}}=d-200 / K_{\mathrm{O}_{\mathrm{a}}} .
\end{gathered}
$$

$$
-\Delta \mathrm{H}_{2}=H_{i}-H_{f}=K_{\mathrm{O}_{2}}\left(a-d-C_{i} / K_{\mathrm{CO}_{2}}\right)-O_{i}+200 .
$$


For simplicity and convenience in deriving the above relations, vesselconstant corrections due to the volume of $\mathrm{KOH}$ added through the vent have not been introduced. In experiments where close approximations are adequate, it is not necessary to apply the corrections for $K_{\mathrm{O}_{2}}$ and $K_{\mathrm{CO}_{2}}$.

\section{RESULTS}

A typical experiment with 3-day old autotrophically grown cells of $\boldsymbol{H}$. facilis is presented in Table 1. It is evident, disregarding the very low endogenous respiration, that the following reactions are effected by $\boldsymbol{H}$. facilis:

$$
\begin{aligned}
& 4 \mathrm{H}_{2}+2 \mathrm{O}_{2} \longrightarrow 4 \mathrm{H}_{2} \mathrm{O}, \\
& 2 \mathrm{H}_{2}+\mathrm{CO}_{2} \longrightarrow \mathrm{H}_{2} \mathrm{O}+\left(\mathrm{CH}_{2} \mathrm{O}\right) \\
& \underset{6 \mathrm{H}_{2}+2 \mathrm{O}_{2}+\mathrm{CO}_{2} \rightarrow 5 \mathrm{H}_{2} \mathrm{O}+\left(\mathrm{CH}_{2} \mathrm{O}\right)}{ }
\end{aligned}
$$

This is the same overall reaction carried out by Gaffron's anaerobically adapted green algae (1942).

\begin{tabular}{|c|c|c|c|c|c|c|}
\hline \multirow{3}{*}{$\begin{array}{l}\text { Uptake of } \\
\mathrm{CO}_{2}\left(\text { as } \mathrm{HCO}_{3}^{-}\right)\end{array}$} & \multirow[b]{2}{*}{$\begin{array}{c}\text { KOH in } \\
\text { centre } \\
\text { well* }\end{array}$} & \multicolumn{5}{|c|}{ Time of observation (min.) } \\
\hline & & \multicolumn{5}{|c|}{$\mu$ l. gas consumed } \\
\hline & - & 11 & 26 & 35 & 48 & $\mathbf{5 1}$ \\
\hline $\mathrm{CO}_{2}$ (total) & - & 14 & 26 & 38 & 46 & $\mathbf{5 5}$ \\
\hline $\mathrm{O}_{2}$ & $\begin{array}{l}+ \\
-\end{array}$ & $\begin{array}{l}27 \\
31\end{array}$ & $\begin{array}{l}54 \\
56\end{array}$ & $\begin{array}{l}76 \\
78\end{array}$ & $\begin{array}{r}102 \\
91\end{array}$ & $\begin{array}{l}114 \\
118\end{array}$ \\
\hline $\mathbf{H}_{2}$ & + & $\begin{array}{l}63 \\
90\end{array}$ & $\begin{array}{l}116 \\
164\end{array}$ & $\begin{array}{l}166 \\
234\end{array}$ & $\begin{array}{l}200 \\
278\end{array}$ & $\begin{array}{l}240 \\
335\end{array}$ \\
\hline $\mathrm{H}_{2}: \mathrm{O}_{2}$ & $\begin{array}{l}+ \\
-\end{array}$ & $\begin{array}{l}2 \cdot 3 \\
2 \cdot 9\end{array}$ & $\begin{array}{l}2 \cdot 1 \\
2 \cdot 9\end{array}$ & $\begin{array}{l}2 \cdot 2 \\
3 \cdot 0\end{array}$ & $\begin{array}{l}1 \cdot 9 \\
3 \cdot 1\end{array}$ & $\begin{array}{l}2 \cdot 1 \\
2 \cdot 9\end{array}$ \\
\hline $\mathrm{H}_{2}: \mathrm{O}_{2}: \mathrm{CO}_{2}$ & - & $6 \cdot 4: 2 \cdot 2: 1 \cdot 0$ & $6 \cdot 3: 2 \cdot 1: 1 \cdot 0$ & $6 \cdot 2: 2 \cdot 0: 1 \cdot 0$ & $6 \cdot 1: 1 \cdot 9: 1 \cdot 0$ & $6 \cdot 1: 2 \cdot 1: 1 \cdot 0$ \\
\hline$Q_{\mathrm{CO}_{2}}$ & - & - & - & 72 & - & - \\
\hline$Q_{\mathrm{O}_{2}}$ & + & $\dot{.}$ & $\dot{.}$ & $\begin{array}{l}145 \\
148\end{array}$ & $\dot{.}$ & $\dot{.}$ \\
\hline $\boldsymbol{Q}_{\mathrm{H}_{2}}$ & $\begin{array}{l}+ \\
-\end{array}$ & $\dot{\cdot}$ & • & $\begin{array}{l}315 \\
446\end{array}$ & $\dot{.}$ & $\dot{.}$ \\
\hline \multicolumn{7}{|c|}{ Endogenous respiration } \\
\hline $\mathbf{O}_{2}$ & + & 0 & 4 & 6 & 8 & 9 \\
\hline $\boldsymbol{Q}_{\mathrm{O}_{2}}$ & + & - & - & 12 & $\cdot$ & - \\
\hline
\end{tabular}

Table 1. Assimilation of $\mathrm{CO}_{2}, \mathrm{H}_{2}$ and $\mathrm{O}_{2}$ by Hydrogenomonas facilis $0.25 \mathrm{mg}$. dry weight equivalent of cells/vessel. $Q$ values calculated from the $60 \mathrm{~min}$. data.

In other experiments under anaerobic conditions described in Tables 2 and 3, the fixation of $\mathrm{CO}_{2}$ could not be demonstrated. During the reduction of nitrate to nitrite with molecular $\mathrm{H}_{2}$, the ostensible fixation of $2 \mu \mathrm{l}$. of $\mathrm{CO}_{2}$ lies well within the experimental error for Warburg work. 
According to calculations from the values cited by Rabinowitch (1945) and Stephenson (1949), both the heat content and free energy from the reduction of nitrate to nitrite by molecular $\mathrm{H}_{2}$ are approximately two-thirds of the corresponding values for the oxyhydrogen reaction with an equivalent amount of $\mathrm{H}_{2}$. For this reason, it was anticipated that during the reduction

$$
\begin{gathered}
\mathrm{H}_{2}+\mathrm{l} / 2 \mathrm{O}_{2} \rightarrow \mathrm{H}_{2} \mathrm{O}+69 \mathrm{kcal} ., \quad \Delta \mathrm{F}=-56 \mathrm{kcal} \text {. } \\
\mathrm{NO}_{3}^{-} \text {(aq.) }+\mathrm{H}_{2} \rightarrow \mathrm{NO}_{2}^{-}+\mathrm{H}_{2} \mathrm{O}+45 \mathrm{kcal} ., \quad \Delta \mathrm{F}=-39 \mathrm{kcal} \text {. }
\end{gathered}
$$

of nitrate about two-thirds as much $\mathrm{CO}_{2}$ would be assimilated per mole of $\mathrm{H}_{2}$ oxidized with nitrate as compared with $\mathrm{O}_{2}$.

Table 2. Inability of Hydrogenomonas facilis to fix $\mathrm{CO}_{2}$ during the reduction of nitrate by molecular $\mathrm{H}_{2}$

$6.0 \mathrm{mg}$. dry weight equivalent of cells/vessel. $Q$ values calculated from the $50 \mathrm{~min}$.

\begin{tabular}{|c|c|c|c|c|}
\hline & \multicolumn{4}{|c|}{ Atmosphere } \\
\hline & \multicolumn{2}{|c|}{$\begin{array}{c}100 \% \mathrm{H}_{2} \\
\mathrm{KOH} \text { in centre well }\end{array}$} & \multicolumn{2}{|c|}{$\begin{aligned} 1 \% & \mathrm{CO}_{2}+99 \% \mathrm{H}_{2} \\
& \text { No KOH }\end{aligned}$} \\
\hline & \multicolumn{4}{|c|}{$\mu$ mole $\mathrm{KNO}_{3}$ tipped from side-arm } \\
\hline & $\mathbf{0}$ & $10 \cdot 0$ & $\mathbf{0}$ & $10 \cdot 0$ \\
\hline $\begin{array}{l}\text { Observed } \mu \mathrm{l} . \text { gas consumed } \\
\mu \mathrm{l} . \mathrm{H}_{2} \text { required for reduction of all } \mathrm{NO}_{3}^{-} \\
\text {to } \mathrm{NO}_{2}^{-}\end{array}$ & $\mathbf{0}$ & $\begin{array}{l}217 \\
224\end{array}$ & 0 & $\begin{array}{l}225 \\
224\end{array}$ \\
\hline $\begin{array}{l}\text { Total } \mu \mathrm{l} . \mathrm{CO}_{2} \text { present at time } 0 \\
\text { Total } \mu \mathrm{l} . \mathrm{CO}_{2} \text { present at end } \\
\mu \mathrm{l} . \mathrm{CO}_{2} \text { fixed }\end{array}$ & $\dot{\cdot} \cdot$ & $\dot{\dot{\varphi}}$ & $\begin{array}{r}295 \\
293 \\
2\end{array}$ & $\begin{array}{r}299 \\
297 \\
2\end{array}$ \\
\hline Endogenc & $\therefore$ & $\begin{array}{l}41 \\
\text { ?n }\end{array}$ & $\dot{0} \cdot 4$ & $\begin{array}{c}43 \\
0 \cdot 4\end{array}$ \\
\hline $\begin{array}{l}\text { Total } \mu 1 . \mathrm{CO}_{2} \text { evolved } \\
Q_{\mathrm{CO}_{2}}\end{array}$ & $\dot{\cdot}$ & $\dot{.}$ & $\begin{array}{l}-2 \cdot 0 \\
-0 \cdot 4\end{array}$ & $\dot{.}$ \\
\hline
\end{tabular}
interval required for the actual reduction of nitrate.

The inability of $\boldsymbol{H}$. facilis to fix $\mathrm{CO}_{2}$ during the reduction of nitrate was surprising. The organism grows well autotrophically with nitrate as the sole source of nitrogen, and such cultures give an intense test for nitrite (Schatz \& Bovell, 1952). This ruled out the possibility that nitrate inhibited the chemosynthetic assimilation of $\mathrm{CO}_{2}$ by $\mathrm{H}$. facilis as it does the photosynthetic fixation of $\mathrm{CO}_{2}$ by Chlorella pyrenoidosa (Warburg \& Negelein, 1920), which van Niel (1949) has considered to be a competition between nitrate and $\mathrm{CO}_{2}$ as $\mathrm{H}$-acceptors in the photolysis of $\mathrm{H}_{2} \mathrm{O}$. Since $\mathrm{H}$. facilis failed to apply the energy released from the oxidation of $\mathrm{H}_{2}$ by nitrate for the fixation of $\mathrm{CO}_{2}$ anaerobically, it differs from Thiobacillus thiooxidans. Vogler \& Umbreit (1942) found that $\boldsymbol{T}$. thiooxidans was capable of accumulating in organic phosphate esters the energy derived from the aerobic oxidation of sulphur in the absence of $\mathrm{CO}_{2}$, and subsequently utilizing this energy store for the assimilation of $\mathrm{CO}_{2}$ under anaerobic conditions.

$H$. facilis also did not consume $\mathrm{CO}_{2}$ in an atmosphere of $\mathrm{H}_{2}$ and $\mathrm{CO}_{2}$ even after $20 \mathrm{hr}$. (Table 3). With Rhodospirillum rubrum, the photoreduction of 
$\mathrm{CO}_{2}$ began only after an adaption period of 8 to $9 \mathrm{hr}$. (Foster, 1944). With H. facilis there was no uptake of $\mathrm{CO}_{2}$ or $\mathbf{H}_{2}$ in the presence of pyruvate, $\alpha$-ketoglutarate, or acetone (Table 3 ). The assimilation of $\mathrm{CO}_{2}$ is in considerable measure mediated by a carboxylation of pyruvate and $\alpha$-ketoglutarate (Ochoa, 1951).

Table 3. Inability of $\mathrm{Hydrogenomonas} \mathrm{facilis} \mathrm{to} \mathrm{assimilate} \mathrm{CO}_{2}$ and $\mathrm{H}_{2}$ in the presence of pyruvate, $\alpha$-ketoglutarate, or acetone

\begin{tabular}{|c|c|c|c|c|}
\hline $\begin{array}{l}\text { Supplement tipped } \\
\text { from side-arm }\end{array}$ & Atmosphere & $\begin{array}{c}\text { Duration } \\
\text { of } \\
\text { experi- } \\
\text { ment } \\
\text { (hr.) }\end{array}$ & $\begin{array}{l}\text { Dry } \\
\text { weight } \\
\text { equivalent } \\
\text { of cells } \\
\text { (mg.) }\end{array}$ & Results \\
\hline $\begin{array}{l}\text { Pyruvate,* } \\
10 \cdot 0 \mu \text { mole }\end{array}$ & $2 \% \mathrm{CO}_{2}+98 \% \mathrm{H}_{2}$ & $2 \cdot 8$ & 16 & $\begin{array}{l}\text { No change in bicarbonate } \\
\text { concentration or mano- }\end{array}$ \\
\hline $\begin{array}{l}\alpha \text {-Ketoglutarate, } * \\
10 \cdot 5 \mu \text { mole }\end{array}$ & $1 \% \mathrm{CO}_{2}+99 \% \mathrm{H}_{2}$ & $1 \cdot 4$ & 13 & $\begin{array}{l}\text { metric reading. Rapid } \\
\text { gas uptake upon intro- }\end{array}$ \\
\hline Acetone, $10 \cdot 0 \mu$ mole & $1 \% \mathbf{C O}_{2}+\mathbf{9 9} \% \mathrm{H}_{2}$ & $1 \cdot 8$ & 11 & duction of air \\
\hline None & $1 \% \mathrm{CO}_{2}+99 \% \mathbf{H}_{2}$ & 20 & 30 & \\
\hline None & $\begin{array}{l}1 \% \mathrm{CO}_{2}+89 \% \mathrm{H}_{2}+ \\
10 \% \text { air }\end{array}$ & $\mathbf{1}$ & 0.25 & $38 \mu \mathrm{l} \mathrm{CO}{ }_{2}$ fixed. (Table 1) \\
\hline
\end{tabular}

\section{DISCUSSION}

The respirometric method of analysis developed here requires actually only the determination of bicarbonate, and total initial $\mathrm{CO}_{2}$ and $\mathrm{O}_{2}$ gases in the control vessel at zero time. With this information plus the values for the gas volume of the filled flask, the constants $K_{\mathrm{O}_{\mathrm{s}}}$ and $K_{\mathrm{CO}_{\mathrm{a}}}$, and the manometric readings $a, b, c$, and $d$ corrected for thermobarometric variation, it is easy to calculate the net exchange of $\mathrm{H}_{2}, \mathrm{O}_{2}$, and $\mathrm{CO}_{2}$ independently in flasks gassed from the same mixture. Despite the numerous operations to which each manometer is subjected, the results obtained have been well within the range of experimental error conventionally accepted for simpler operations with the Warburg apparatus.

The author is indebted to $\mathrm{Dr}$ C. B. van Niel for encouragement and advice, and to Dr R. H. Burris of the Department of Biochemistry at the University of Wisconsin for comments on the respirometric method.

\section{REFERENCES}

Foster, J. W. (1944). Oxidation of alcohols by non-sulfur photosynthetic bacteria. J. Bact. 47, 355.

GAFFron, H. (1942). Reduction of carbon dioxide coupled with the oxyhydrogen reaction in algae. $J$. gen. Physiol. 26, 241.

OchоA, S. (1951). Biological mechanisms of carboxylation and decarboxylation. Physiol. Rev. 31, 56.

Rabinowitch, E. I. (1945). Photosynthesis and Related Processes, pp. 112 and 116. New York: Interscience Publishers, Inc.

Schatz, A. \& Bovell, Jr., C. (1952). Growth and hydrogenase activity of a new bacterium, Hydrogenomonas facilis. J. Bact. 63, 87. 
Stephenson, M. (1949). Bacterial Metabolism, 3rd. edn, pp. 245, 246 and 267. London: Longmans, Green \& Co.

Umbreit, W. W., Burris, R. H. \& Stauffer, J. F. (1949). Manometric Technics and Tissue Metabolism, 2nd edn, p. 58. Minneapolis: Burgess Publishing Co.

van Niel, C. B. (1949). The comparative biochemistry of photosynthesis. In Photosynthesis in Plants, p. 437, edited by Franck, J. \& Loomis, W. E. Ames, Iowa: Iowa State College Press.

Vogler, K. G. \& UmbreIT, W. W. (1942). Studies on the metabolism of the autotrophic bacteria. III. The nature of the energy storage material active in the chemosynthetic process. J. gen. Physiol. 26, 157.

Warburg, O. \& Negelein, E. (1920). Über die Reduktion der Salpetersäure in grünen Zellen. Biochem. Z. 110, 66.

(Received 15 October 1951) 